\title{
The Relationship between Metacognitive Skills and Cognitive Learning Outcomes through Guided Inquiry Model
}

\author{
Murni Sapta Sari' ${ }^{1 . a}$, Sunarmi $^{1}$, and Amy Tenzer ${ }^{1}$ \\ ${ }^{1}$ Biology Education Study Program, Mathematics and Science Faculty, UniversitasNegeri Malang \\ Malang, Indonesia \\ e-mail: amurni.sapta.fmipa@um.ac.id
}

\begin{abstract}
The result of observations on several high schools in Malang regency showed that the teachers had not implemented metacognitive strategies in Biology learning process. The general impact is the students have not empowered their metacognitive skills such as awareness of planning, monitoring, and evaluating their learning process. Learning strategy is needed, one of the efforts is by using guided inquiry model. This paper seeks to address the correlation between metacognitive skill and the result of cell material learning through the guided inquiry learning model at the XI high school students in Malang Regency. The research design is descriptivecorrelational research. This research was conducted in SMA Malang Regency. The samples were the students of class XI MIA-2 SMA Islam Kepanjen which consists of 32 students, class XI MIA-1 SMA Al Maarif which consists of 27 students and class XI MIA-2 SMA AN Noor Malang which consists of 28 students. The determination of the sample in this research was administered by random sampling technique. The instruments which are employed in this research consist of the syllabus, Learning Implementation Plan (RPP), Student Worksheet (LKS), and questionnaire, observation sheets of the instructional syntax of learning, metacognitive skill rubrics, and test of learning outcomes. The Data were analyzed by using simple regression analysis with SPSS for Windows software and performed at $5 \%$ significant level. The results showed there was a correlation between metacognitive skills and student cognitive learning outcomes through the application of guided inquiry model. The amount of contribution of metacognitive skill to cognitive learning result of the student is $37,2 \%$.
\end{abstract}

Keywords-learning strategy, metacognitive skills, inquiry model.

\section{INTRODUCTION}

The final destination for the quality of education in Indonesia is to improve the quality of the whole human being so that the competency standard of graduates (SKL) in Curriculum 2013 includes attitude, knowledge, and skills. Metacognition skill is one SKL of the aspects of knowledge that must be mastered by high school students in the domain of knowledge, therefore must be derived in each subject. The ability of metacognition is the awareness of the individual in his thought process of planning, monitoring and assessing his cognitive processes and strategies [1]. Metacognition consists of two components of metacognition knowledge and metacognitive experiences that are often called metacognitive skills $[1,2]$. Through metacognitive skills, students are expected to learn biology more independently and are required to have learning experiences which can help students to think like a biologist. A biologist is always interested and concerned about a natural phenomenon, always want to know what, how, and why about a phenomenon of nature and its causal relationship through the scientific method [3].

The result of observations on several grade XI of high schools in Malang regency showed that the teachers had not implemented metacognitive strategies in biology learning. The impact is generally shown that students have not yet empowered their metacognitive skills such as awareness of planning, monitoring and evaluating of their learning process. For example, students who are supposed to finish their homework in the classroom by cheating their friends. Besides, the students receive only the knowledge which is provided by the teacher and have no attempt to improve their ability by looking for other sources of information. Based on the interviews with the students indicated that the students do not like to learn biology because many things to be memorized and boring. The result of teachers' assessment shows more at the level of low cognitive which is on remembering. Metacognitive strategies are needed so that the students can learn more meaningfully rather than just a collection of facts.

\section{METHODS}

The research design which was administered is descriptive-correlational research. This research was conducted in SMA Islam Kepanjen, SMA Al Maarif, and SMA AN Noor Bululawang Malang Regency. Population in this research is all students of class XI in Malang Regency region while the sample is student of class XI MIA-2 SMA Islam Kepanjen which is consisting of 32 students, student of class XI MIA-1 SMA Al Maarif which is consisting of 27 students and student of class XI MIA -2 SMA AN Noor Malang which is consisting of 28 students. Random sampling technique did the determination of the sample in this study. The instruments which were used in this study consist of the syllabus, Learning Implementation Plan (RPP), Student Worksheet (LKS), questionnaire, observation sheet of instructional syntax, metacognitive skill rubrics and test of learning result. The data were analyzed by using simple regression analysis with SPSS for Windows software and performed at 5\% significant level. 


\section{RESULTS AND DISCUSSION}

Normality test was done before hypothesis test to find out whether data is normally distributed or not. Based on the Kolmogorov-Smirnov test it is known that the metacognitive skills data, as well as the learning outcomes, are normally distributed. Based on the result of hypothesis test between metacognitive skill and cognitive learning outcomes of the.e students on the application of guided inquiry model obtained the value of $F$ equal to 52,160 with significance value 0,000 $<0,05$ which can be seen in Table 1 . Thus, it shows that the null hypothesis is rejected and the research hypothesis is accepted so that there is a relationship between metacognitive skills and student cognitive learning outcomes in the application of guided inquiry model. Based on the regression test results obtained regression equation is $\mathrm{Y}=32.701+$ $0.386 \mathrm{X} 1$. The correlation coefficient $(\mathrm{r})$ obtained is 0.610 which can be interpreted that the correlation between metacognitive skills and cognitive learning outcomes in the application of guided inquiry model is quite strong. The value of the coefficient of determination (r2) is 0.372 which is presented in Table 2. The amount of contribution of metacognitive skills to cognitive learning outcomes of students is $37.2 \%$.
Based on the results of hypothesis testing, it is obtained $\mathrm{F}$ value of 52,160 with a significance value of $0.000<0.05$ which means that there is a relationship between metacognitive skills and student cognitive learning outcomes through the application of guided inquiry model. The task of inquiry learning acts as a whole [6]. The scientific inquiry cycle begins with the exploration of phenomena, investigative questions, proving hypotheses through experimentation, validating evidence by analyzing and building new knowledge. Through tasks in inquiry learning that imitate a real scientist in the simplest and most common form, the students construct and develop knowledge on the content of science, and at the same time develop inquiry skills, understand the nature of science and scientific thinking. The complexity of the tasks in inquiry learning and its qualities that require students to take a systematic and reflective approach to obtain valid and accurate conclusions, therefore inquiry learning is a domain that emphasizes metacognition.

Table 1. The summary of Anova Test Results for the Relationship of Metacognitive Skills to Learning Outcomes

\begin{tabular}{|c|c|c|c|c|c|c|}
\hline \multicolumn{2}{|c|}{ Model } & $\begin{array}{c}\text { Sum of } \\
\text { Squares }\end{array}$ & Df & $\begin{array}{c}\text { Mean } \\
\text { Square }\end{array}$ & F & Sig. \\
\hline \multirow{2}{*}{1} & Regression & 2632,049 & 1 & 2632,049 & 52,160 & ,000 $^{\text {c }}$ \\
\cline { 2 - 7 } & Residual & 4440,609 & 88 & 50,461 & & \\
\cline { 2 - 6 } & Total & 7072,658 & 89 & & & \\
\hline \multicolumn{7}{|c|}{ a. Interaction = inquiry } \\
\hline \multicolumn{7}{|c|}{ c. Predictors: (Constant), Y metacognitive skill } \\
\hline
\end{tabular}

Table 2. The summary of Regression Results

\begin{tabular}{|c|c|c|c|c|}
\hline Model & $\mathbf{R}$ & $\begin{array}{c}\text { R } \\
\text { Square }\end{array}$ & $\begin{array}{c}\text { Adjusted R } \\
\text { Square }\end{array}$ & $\begin{array}{c}\text { Std. } \\
\text { of the Estimate }\end{array}$ \\
\hline 1 & $\mathbf{, 6 1 0}^{\mathbf{b}}$ & $\mathbf{3 7 2}$ & $\mathbf{3 6 5}$ & $\mathbf{7 , 1 0 3 6 2}$ \\
\hline \multicolumn{6}{|c|}{ a. Interaction = Low Inquiry } \\
\hline
\end{tabular}

The results of self-reflection questionnaires and interviews show that the students respond positively to inquiry learning strategies. Successful implementation of inquiry learning strategy because of two things that are located from student attention and instruction from LKS through guided inquiry model. The research undertaken focuses on biological learning with the material integrating the structure on cell function. Activity begins with the exploration of phenomena that require the students' skills in analyzing the linkage of structures to cell function. The students are required to think productively during learning to solve problems related to daily student life. The learning that requires students to engage in the use of various cognitive processes that emphasize thinking skills, if it is dismissed will cause students cognitive burden. The integration of both can be executed by using a metacognitive strategy which is guided inquiry learning model.

There are three strategies which are used to improve metacognitive skills by applying learning models, diagrams, and practices [7]. The guided inquiry model is one of the learning models that take into account the discovery and metacognitive skills of the students. The inquiry learning model has several advantages as follows. 1) student-centered learning and self-concept development; 2) be able to prevent the students from learning by memorizing; 3) provide 
sufficient time for the students to accommodate and assimilate information; 4) gives the students the freedom to learn independently [8]. Metacognitive skills are influenced by learning strategies [9]. Learning strategies can be classified into two groups based on the depth of their cognitive processes, including, e.g., superficial processing strategies (e.g., memorization of information) or more indepth processing strategies (e.g., organization, elaboration, and monitoring of information).

Generally, high school biology teachers in Malang Regency in their learning activities have not implemented the metacognitive strategy. The emergence of this issue is supported by the opinion that the view of science as a discipline, in the learning process and assessment contrary to what happens in schools in general in fact [10]. It causes misconception in the students who assume that science is a collection of facts. Misconceptions about the process of science because of the lack understanding of the teachers toward science, and rarely reinforce the necessary habits to think like a scientist. The focal point of the problem most likely is in the process of inquiry learning strategy is not the teacher's mistake, because in traditional learning the teachers have not done the process of science interpreting. Process skills in science learning are considered as burdensome by the teachers in high school who lack experience in conducting authentic science research. The integration between the inquiry process and the construction of science is a complex and required a hard work effort from the teacher. To make the necessary changes in metacognitive strategies for teachers is needed as a step to bridge between inquiry on pedagogy in the implementation of curriculum and materials in the classroom.

The implementation of guided inquiry model aimed to achieve the goal by using performance assessment. The performance assessments can be used to increase high-level thinking including metacognitive skills [11]. The merits of performance assessment are directly measurable. Assessment development is aimed to find out the achievement of science learning, not only rely on products but also the process of science, one of which is the process of thinking. The whole of this requires a change in the approaches and techniques of student learning assessments. The skills of the teachers in conducting the assessment will have a tremendous impact on the quality of graduates in each school. The proper assessment must meet the following characteristics. (1) have a clear purpose, (2) linking the learning objectives to the applicable curriculum, (3) general function to improve students' ability to understand complex material; (4) have more than one correct answer, (5) lead to deep understanding, not only on the surface, (6) enhancing students' cognitive abilities and supporting high-level thinking skills, and (7) enhancing metacognitive skills [11].

The results of data analysis showed that metacognitive skills could improve student learning outcomes through inquiry model, the amount of contribution of metacognitive skill to cognitive learning result of students is $37,2 \%$. This result is in accordance that metacognitive skills can improve learning outcomes [12]. The learning that integrates metacognition is an important thing to do because students need to be trained and cultivated to use systematic thinking skills in solving the problems. Metacognition is an essential way to learn effectively in complex situations. The metacognition-based learning process is an attempt to introduce new skills and beliefs in providing practical learning applications to improve student learning outcomes. Metacognition is a mind control and control, so the term refers to one's skills in planning, monitoring and using cognitive strategies and awareness of the activities being performed [13]. Through metacognitive skills, each student is expected to be self-sufficient to determine what will be learned, be able, to be honest about the abilities and shortcomings possessed, dare to try new things to explore knowledge, and is expected to improve learning outcomes.

In the 2013 curriculum, the demands of graduate competency standards are the competence of attitudes, knowledge, and skills. Therefore, in the research that has been done need to conduct an attitude assessment. The assessment of attitudes is an essential part of shaping integrity in student life. Guided inquiry is a learning strategy based on constructivism that should focus on providing a physical experience of cognitive conflict and encouraging students to develop new knowledge in the classroom [4]. The classroom is where students actively interact with friends in understanding phenomena with different individual views. Working in a laboratory is active learning that is consistent with student-center strategies. Based on the approach, constructivist learning is considered an essential part of science learning. Therefore guided inquiry model can be used to empower attitude evaluation to students in class such as cooperation, honesty, discipline.

\section{CONCLUTION}

Based on the findings, it can be concluded that there is a strong relationship between metacognitive skills to cognitive learning outcomes of grade XI students on Biology learning with the application of guided inquiry model. The contribution of metacognitive skills to cognitive learning outcomes was $37.2 \%$. Regression equation obtained is $\mathrm{Y}=$ $32,701+0,386 \times 1$.

\section{REFERENCES}

[1] Flavel, Metacognitive and Cognitive Monitoring, (American Standard University), 1979

[2] E.R. Lai, Metacognition: A Literature Review. Research Report. http://www.pearsonassessments.com/research, 2011

[3] K.D. Tanner, "Feature approaches to biology teaching and learning promoting student metacognition," CBE Life Science Education vol. 11, pp 113-120, 2012

[4] D. Llewellyn, Teaching High School Science Through Inquiry and Argumentation, USA: Crown, 2013

[5] A.J. Garrett, M.M.M. Mazzocco, L. Baker, "Development of the metacognitive skills of prediction and evaluation in children with or without math disability," Learning Disabilities Research \& Practice vol.21(2), pp 77-87, 2006,

[6] Z.R. Dedic, "Metacognitive knowledge in relation to inquiry skills and knowledge acquisition within a computer-supported inquiry learning environment," Psychological Topics vol. 23(1), pp 115-41, 2014

[7] A.K. Ellis, W.D. Denton, J.B. Bond, "An analysis of research on metacognitive teaching strategies," Social and behavior Science, vol.116, pp 4015-24, 2013

[8] R. Syafitri, Asyitas, R. Asyhar, Asrial, "Pengaruh model inkuiri traning dan berpikir kritis terhadap kemampuan berpikir ilmiah pada mata kuliah kimia dasar, EduSains vol.5(1), 2016 
[9] E. Norman \& B. Furnes, "The relationship between metacognitive experiences and learning: Is there a difference between digital and non-digital study media?, " Computers in Human Behavior, 2016

[10] K.D. Seraphin, P. Joanna, K. Lauren \& M.V. Lisa, "Metacognition as means to increase the effectiveness of inquirybased science education," Science Education International, vol.23(4), 2012

[11] N.Y.O.M, Sridhar, "Effectiveness of performance assessment on metacognitive skills," Journal of Education and Practice, www.iiste.org ISSN 2222-1735 (Paper) ISSN 222288X (Online), vol. 3(10), 2012

[12] F. Gul \& S. Shehzab, "Relationship between metacognition, goal orientation, and academic," Achievement Procedia - Social and Behavioral Sciences vol. 47, pp 1864-8, 2012

[13] H.F. O’Neil, J. Abedi, "Reliability and validity of a state metacognitive inventory: Potential for alternative assessment," Journal of Educational Research, vol.89, pp 234-45, 1996 